\title{
A historical record of ammonium concentrations from a glacier in the Alps
}

\author{
A. Döscher, H.W. Gäggeler', U. Schotterer ${ }^{2}$, and M. Schwikowski *
}

\begin{abstract}
Ammonia is the primary gaseous alkaline species in the atmosphere over Europe, neutralising up to $70 \%$ of the original acidity in precipitation [Buijsman et al., 1987]. It is directly involved in the conversion of sulphur dioxide and nitrogen oxjdes into the aerosol phase. Furthermore, ammonium contributes considerably to the nitrogen deposition and soil acidification which causes extensive changes in plant communities in many ecosystems [Moore, 1995; Rohde et al., 1995]. However, in Europe continuous long-term measurements of atmospheric ammonia or ammonium in precipitation are lacking. Here, we present a continuous, high-resolution record of ammonium in precipitation for the time period 1780 to 1980 deduced from an ice core recovered from a high-altitude glacier in the Alps. The ammonium level remained constant from 1780 to 1870 and increased afterwards by a factor of three. This trend shows that ammonia emissions in Europe have substantially increased in the last 100 years.
\end{abstract}

\section{Introduction}

The dominant emissions of ammonia in Europe arise from agricultural sources, mainly bacterial decomposition of livestock wastes (81\%) and fertiliser applications [Buijsman et al., 1987]. Released to the atmosphere, ammonia can either directly be redeposited to the ground or converted to ammonium ions in cloud droplets or on aerosol particles. Ammonium ions attached to aerosols have a longer atmospheric lifetime than gaseous ammonia. They are therefore transported over longer distances and are mainly deposited by precipitation scavenging. In Europe, no long-term concentration measurements of atmospheric ammonia or aerosol ammonium exist and only a few continuous short-term deposition data sets are available. An increase in ammonium deposition rate was observed for the period 1950 to 1974 at several sites in Europe and was most pronounced in central Europe [Oden, 1976]. Five-year averages of the aminonium concentration in a Colle Gnifetti ice core showed an increasing trend over the last 100 years [Wagenbach et al., 1993; EUROTRAC, 1993]. In contrast, relatively stable concentrations of ammonium were reported in precipitation at Rothamsted, UK, over the period 1880 to 1980 [Brimblecombe and Stedman, 1982]. However, this record is composed of a few data points only, and data from 1920 to 1960 are lacking. Emission invento-

\footnotetext{
To whom the correspondence should be addressed Paul Scherrer Institut, CH-5232 Villigen-PSI, Switzerland

'Also at Departement für Chemie und Biochemie, Universität Bern,

Freiestrasse 3, CH-3012 Bern, Switzerland

${ }^{2}$ Also at Physikalisches Institut, Universität Bern, Sidlerstr. 5, CH-3012 Bern, Switzerland
}

Copyright 1996 by the American Geophysical Union.

Paper number 96GL02615.

0094-8534/96/96GL-02615\$05.00 ries estimate a $50 \%$ increase in ammonia emissions over Europe between 1950 and 1980 [ApSimon et al., 1987]. By combining a long-range transport model with historical emission inventories, a doubling of ammonium in precipitation in Europe between 1870 and 1980 was assessed [Asman et al., 1988].

Continuous long-term deposition records can be gained from ice archives, i.e. from polar ice sheets and glaciers. High resolution ammonium measurements from a Greenland ice core showed no overall anthropogenic increase over the last 300 years [Mayewski et al., 1993; Fuhrer et al., 1996]. Spikes of ammonium measured in cores from different sites in Greenland have been attributed to biomass burning events [Whitlow et al., 1994; Taylor et al., 1996; Legrand et al., 1992]. However, the main source area for ammonium deposited on the Central Greenland ice sheet is considered to be northern North America [Fuhrer et al., 1996]. In contrast, records from glaciers in the Alps are suitable for the reconstruction of a European emission history [Oeschger et al., 1977; Schotterer et al., 1985; Wagenbach, 1889; Maupetit et al., 1995]. The prerequisite of conservation of the analyte over extended time periods, i.e. the absence of deep meltwater percolation, is, however, fulfilled by a few cold highaltitude glaciers only.

\section{Experimental and Dating of the Ice Core}

The ammonium record was reconstructed from a $109 \mathrm{~m}$ ice core electromechanically drilled close to bedrock in 1982 on the glacier saddle Colle Gnifetti, Monte Rosa massif, 4450 a a.s.l., Switzerland. Details of the site and the glacio-chemical studies previously performed there are given elsewhere [Oeschger et al., 1977; Schotterer et al., 1985; Wagenbach, 1989; Döscher et al., 1995; Haeberli et al., 1983]. Core sections of 0.5 to $0.9 \mathrm{~m}$ length with a diameter of $7.5 \mathrm{~cm}$ were sealed at the site in polyethylene bags and kept frozen at $-30^{\circ} \mathrm{C}$ until the processing started in 1993. The outer part of the core was removed mechanically at $-10^{\circ} \mathrm{C}$ to reduce surface contamination and 2.5 to $5 \mathrm{~cm}$ samples were analysed by ion chromatography [Döscher et al., 1995]. Dating of the ice core was performed using distinct stratigraphic markers such as historically known Saharan dust events in 1901/02, 1936/37 and 1977 (identified by yellowish layers accompanied by high concentrations of calcium), the atomic bomb horizon in 1963 (identified by tritium measurements) and volcanic eruptions (identified by high sulphate concentrations accompanied by high sulphate to calcium ratios) [Döscher et al., 1995; 1996]. For the volcanoes, the time of eruption was used (1912: Katmai, Alaska, 1883: Krakatau, Indonesia, 1815: Tambora, Indonesia, 1783: Laki, Iceland; from Bradley and Jones [1992]). In order to obtain a continuous time scale the time markers were used to fit the accumulation rate of a simplified ice flow model allowing for thinning of the ice [Johnsen et al., 1972]. The resulting time scale was corroborated by continuous measurements of ${ }^{210} \mathrm{~Pb}$ (until 1900) and by a three-dimensional ice flow model [Wagner, 1994]. 


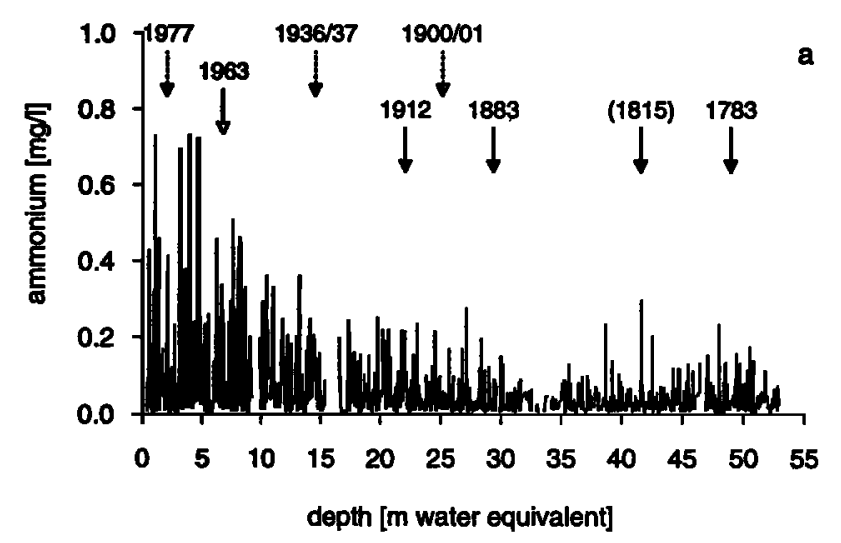

Figure 1a. Ammonium concentrations in an alpine ice core covering the time period 1780 to 1980 . Stratigraphic markers used for dating such as historically known Saharan dust events in 1901/02, 1936/37 and 1977 (dashed arrows), the atomic bomb horizon in 1963 (open arrow) and volcanic eruptions (solid arrows) [Döscher et al., 1995; Döscher et al., in preparation] are indicated.

\section{Results and Discussion}

In the present work, the ammonium record consisted of a total of 1308 samples and is displayed in Fig. 1a. Large concentration fluctuations are observed which we attribute to seasonal effects. This is illustrated in Fig. lb by magnification of the record covering the time period 1963 to 1977 . Extremely low and high ammonium concentrations represent winter and summer snow, respectively. This strong seasonality is typical for aerosol related species in the atmosphere or in snow at high-alpine sites. In summer, polluted air from the planetary boundary layer is transported up to these high altitudes by convection, whereas in winter, the strong atmospheric stability prevents this transport. Hence, in the winter high-alpine sites experience free tropospheric conditions. The result is a summer to winter ratio of the aerosol concentration of about ten [Baltensperger et al., 1991]. The concentration of the aerosol species in snow reflects the pronounced seasonality of the atmospheric aerosol concentration. In the case of ammonium, the seasonality due to atmos-

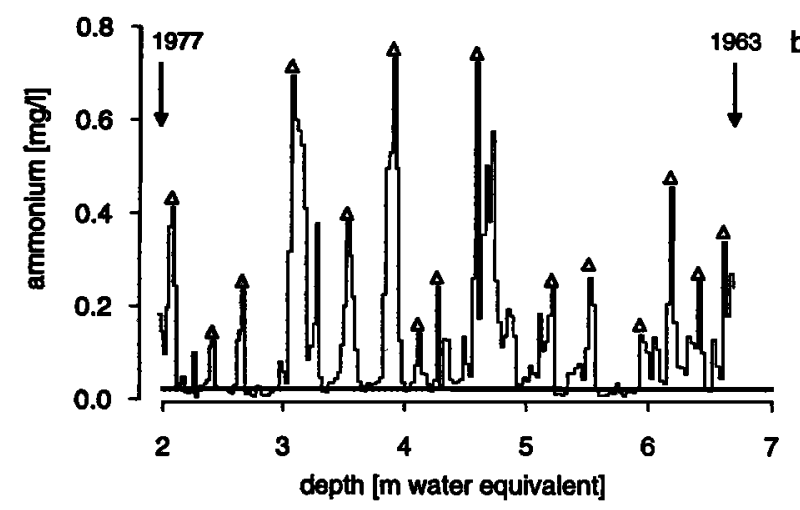

Figure 1b. Magnification of a $5 \mathrm{~m}$ part of the record for a depth range between 2 to $8 \mathrm{~m}$ water equivalent. The two time markers 1977 and 1963 define the period. The annual layer counting method is illustrated by triangles indicating the identified ammonium summer maxima. The dashed line represents the ammonium concentration in winter snow $(0.01 \mathrm{mg} / \mathrm{l})$ defined as 5th percentile (see also Fig. 3). pheric transport is augmented by the seasonal variation of the emissions, because the agricultural activities from which ammonia is principally derived are maximal in summer.

In contrast to the Greenland ice sheet, where ammonium spikes are indicative for biomass burning events (see above), high concentrations of ammonium at Colle Gnifetti in the period from about 1900 to 1980 are accompanied by high concencentrations of sulphate and nitrate, which points to an anthropogenic origin [Döscher et al., 1996]. In preindustrial times, a correlation was observed only between ammonium and nitrate, possibly indicating that the contribution of the biomass burning source was more important. However, future research is needed to corroborate these findings, including the analysis of complementary tracers of biomass burning.

An additional feature of the data is illustrated by Fig. 1b: The observed net accumulation rate of $0.3-0.4 \mathrm{~m} \mathrm{y}^{-1}$ water equivalent is low. This value represents only a small fraction of the estimated total precipitation rate at this altitude. The deficit is caused by wind erosion of fresh snow at the exposed glacier saddle, preferentially removing most of the winter precipitation [Maupetit et al., 1995; Döscher et al., 1995]. The observed concentration minima are in agreement with average winter snow values determined at Col du Dome in the Mont Blanc area (about $0.02 \mathrm{mg} / \mathrm{l}$, [Maupetit et al., 1995]). The fact that these winter snow values could be identified is of importance in a different context: It indicates that contamination of the firn and ice, which could have occurred during storage of the core for several years, was negligible.

Fig. 2 shows ten-year average ammonium concentrations for the period 1780 to 1980 . Concentrations increased by a factor of about three between 1870 and 1980 . Our results are in agreement with five-year averages for the period 1880 to 1980 , which were obtained from an ice core drilled at the northern slope of Colle Gnifetti [Wagenbach et al., 1993]. Simultaneous to the increase of ammonium at about 1870 , the upward trend of the sulphate concentrations began (see Fig. 3b, for details we refer to Döscher et al. [1995]). This may indicate that the increase of ammonium is rather caused by an enhanced conversion of ammonia into aerosolborne ammonium due elevated concentrations of sul-

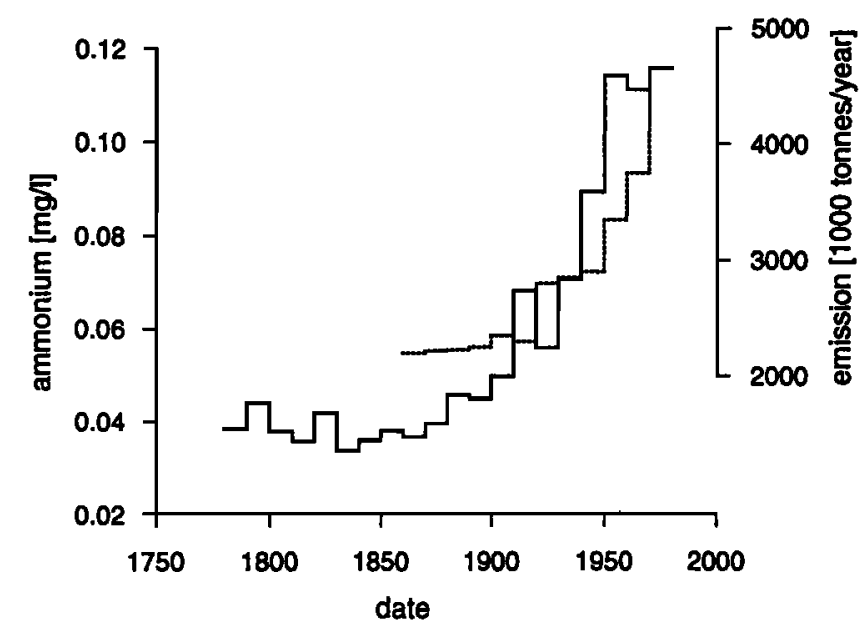

Figure 2. Ten-year average ammonium concentrations for the period 1780 to 1980 (solid line; $n$ varied between 42 and 96). In addition, anthropogenic ammonia emissions from animal manure and application and production of fertilisers in Europe estimated for the period 1870 to 1980 are shown (dashed line, adopted from Asman et al. [1988]). 


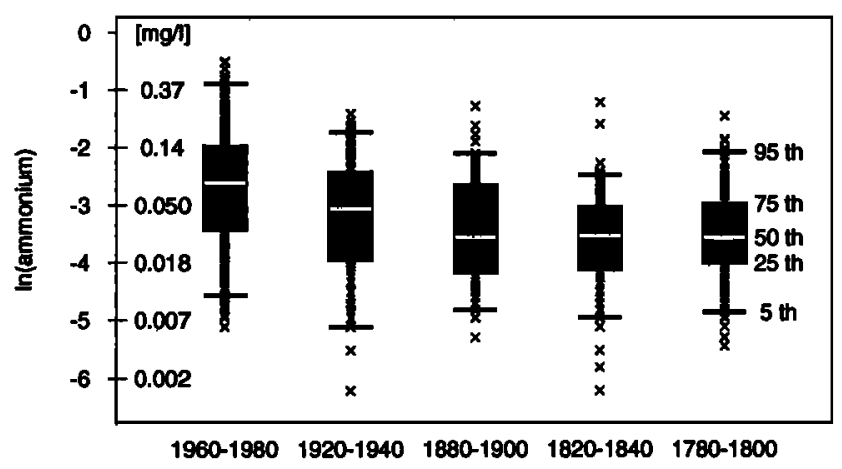

Figure 3a. Box plots for five different 20 -year periods. The 5 th, 25th, 75th, and 95th percen-tiles of the natural logarithm of the ammonium concentrations are shown as well as the median. The numbers of observations for each period were $n=179,163,113$, 91,115 , respectively (from left to right).

phuric acid aerosol than by a change of the ammonia emissions. However, between 1900 and 1980 the molar ratio of ammonium to sulphate decreased significantly, which we interpret by a steeper increase of the emissions of $\mathrm{SO}_{2}$ than those of $\mathrm{NH}_{3}$. The excess of sulphate suggests that the conversion of ammonia into ammonium was maximal. Thus, we assume that from the beginning of this century the ammonium concentrations at Colle Gnifetti are representative for emissions of ammonia in Europe. Superimposed in Fig. 2, emissions estimated from livestock statistics for Europe are shown for the period 1870 to 1980 (data from Asman et al. [1988]), suggesting an increase by a factor of two. We adjusted the recent emission estimates to the 1970-1980 concentration level. The agreement between the trend in our measurements and in the estimated emissions is reasonable. However, the historical emissions seem to be slightly overestimated, possibly due to uncertainties in past livestock data. We conclude that the concentration level of about $0.035 \mathrm{mg} / \mathrm{l}$ in the 19 th century represents a natural background. This record offers the unique potential to determine historical emissions from measured data and to calculate historical depositions. We are aware that a quantitative interpretation of a concentration record with respect to emissions presumes that the general atmospheric transport pattern as well as the scavenging processes remained unchanged during the considered period of time.

In contrast to other anthropogenic species like sulphate and nitrate [Döscher et al., 1995]., those ammonium concentrations associated with winter snow did not show an increasing trend

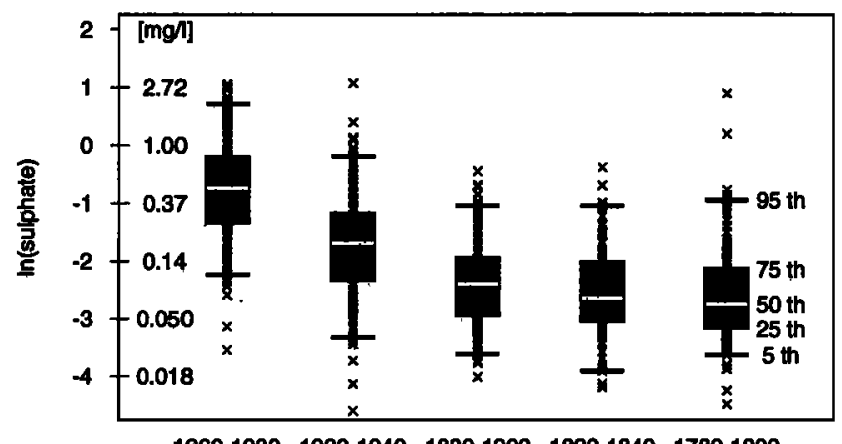

1960-1980 1920-1940 1880-1900 1820-1840 1780-1800

Figure 3b. Same as Fig. 3a, but for sulphate concentrations (from Döscher et al. [1995]). over the time period investigated. This fact is illustrated in Fig. $3 \mathrm{a}$ for five different 20 -year periods. The 5 th percentile remained constant at about $0.01 \mathrm{mg} / \mathrm{l}$, whereas the 95 th percentile reflects the observed increase. In the case of sulphate (Fig. 3b, data from Döscher et al. [1995]) the corresponding 5th and 95th percentiles showed a similar trend indicating that anthropogenic emissions also influence winter snow. In winter, when emissions of $\mathrm{SO}_{2}$ peak and the photochemical conversion to sulphate is slow, the lifetime of $\mathrm{SO}_{2}$ is significantly longer compared to that of $\mathrm{NH}_{3}$. Gaseous $\mathrm{SO}_{2}$ has a remarkably higher diffusion coefficient than aerosol particles resulting in considerable exchange of $\mathrm{SO}_{2}$ between the planetary boundary layer and the free troposphere.

Acknowledgements. The generous offer by Prof. H. Oeschger and coworkers to use the ice core material for our study is highly appreciated. We thank W.A. Asman, H.R. von Gunten and C.N. Hewitt for their helpful comments. This work was supported by the Swiss National Science Foundation (Project NFP-31).

\section{References}

ApSimon, H.M., M. Kruse and J.N.B. Bell, Ammonia emissions and their role in acid deposition. Atmos. Environment, 21, 1939-1945, 1987.

Asman, W.A.H., B. Drukker and A.J. Janssen, Modelled historical concentrations and depositions of ammonia and ammonium in Europe. Atmos. Environment, 22, 725-735, 1988.

Baltensperger, U., H.W. Gäggeler, D.T. Jost, M. Emmenegger and W. Nägeli, Continuous background aerosol monitoring with the epiphaniometer. Atmos. Environment, 25A, 629-634, 1991.

Bradley, R.S. and P.D. Jones, in Climate Since A.D. 1500, R.S. Bradley and P.D. Jones (eds.) pp. 606-622, Routledge, London, 1992.

Brimblecombe, P. and D.H. Stedman, Historical evidence for a dramatic increase in the nitrate component of acid rain. Nature, 298, 460-462, 1982.

Buijsman, E., H.F.M. Maas and W.A.H. Asman, Anthropogenic $\mathbf{N H}_{3}$ emissions in Europe. Atmos. Environment, 21, 1009-1022, 1987.

Döscher, A., H.W. Gäggeler, U. Schotterer and M. Schwikowski, A 130 years deposition record of sulfate, nitrate and chloride from a highalpine glacier. Water, Air and Soil Pollution, 85, 603-609, 1995.

Döscher, A., M. Schwikowski and H.W. Gäggeler, Cation trace analysis of snow and fim samples from high-alpine sites by ion chromatography. J. Chromatogr., A 706, 249-252, 1995.

Döscher, A., H.W. Gäggeler, U. Schotterer and M. Schwikowski, Manuscript in preparation, 1996.

EUROTRAC Annual Report Part 1, EUROTRAC International Scientific Secretariat (ed.), Garmisch-Partenkirchen, pp. 17-18, 1993, unpublished.

Fuhrer, K., A. Neftel, M. Anklin, T. Staffelbach and M. Legrand, A high resolution ammonium ice record covering a complete glacial-interglacial cycle. J. Geophys. Res., in press, 1996.

Haeberli, W., U. Schotterer, D. Wagenbach, H. Haeberli-Schwitter and S. Bortenschlager, Accumulation characteristics on a cold, highalpine firn saddle from a snow-pit study on Colle Gnifetti, Monte Rosa, Swiss Alps. J. Glaciol., 29, 260-271, 1983.

Johnsen, S.J., W. Dansgard, H.B. Clausen and C.C. Langway Jr., Oxygen isotope profiles trough the Antarctic and Greenland ice sheets. Nature, 235, 429-434, 1972.

Legrand, M., M. De Angelis, T. Staffelbach, A. Neftel and B. Stauffer, Large perturbations of ammonium and organic acids content in the Summit-Greenland ice core. Fingerprint from forest fires? Geophy. Res. Lett., 19, 473-475, 1992.

Maupetit, F., D. Wagenbach, P. Weddeling, and R.J. Delmas, Seasonal fluxes of major ions to a high altitude cold alpine glacier. Atmos. Environment, 29, 1-9, 1995.

Mayewski, P.A., L.D. Meeker, M.C. Morrison, M.S. Twickler, S.I. Whitlow, K.K. Ferland, D.A. Meese, M.R. Legrand and J.P. Steffensen, Greenland ice core "signal" characteristics: an expanded view of climate change. J. Geophys. Res., 98, 12839-12847, 1993.

Moore, P.D., Too much of a good thing. Nature, 374, 117-118, 1995.

Oden, S., The acidity problem - an outline of concepts. Water, Air and Soil Pollution, 6, 137-166, 1976. 
Oeschger, H., U. Schotterer, B. Stauffer, W. Haeberli and H. Röthlisberger, First results from alpine core drilling projects. Zeitschrift für Gletscherkunde und Glazialgeologie, 13, 193-208, 1977.

Rodhe, H., P. Grennfelt, J. Wisniewski, C. Agren, G. Bengtsson, K. Johansson, P. Kauppi, V. Kucera, L. Rasmussen, B. Rosseland, L. Schotte and G. Sellden, Acid Reign '95? - Conference Summary Statement. In Proc. 5th International Conference on Acidic Deposition, 26-30 June 1995, Göteborg, Water, Air and Soil Pollution, 85, $1-14,1995$.

Schotterer, U., H. Oeschger, D. Wagenbach and K.O. Münnich, Information on paleo-precipitation on a high-altitude glacier Monte Rosa, Switzerland. Zeitschrift für Gletscherkunde und Glazialgeologie, 21, 379-388, 1985.

Taylor, K.C., P.A. Mayewski, M.S. Twickler and S.I. Whitlow, Biomass burning recorded in the GISP2 ice core: a record from eastern Canada? The Holocene 6, 1-6, 1996.

Wagenbach, D. in The Environmental Record in Glaciers and Ice Sheets, H. Oeschger, and C.C. Langway Jr. (eds.), pp. 69-83, John Wiley and Sons, Chichester, 1989.
Wagenbach, D., W. Jung, R. Schajor and S. Preunkert, Retrospective and present state of the anthropogenic aerosol deposition at a high altitude alpine glacier (Colle Gnifetti $4450 \mathrm{~m}$ a.s.l.). ALPTRAC Annual Report 1992, EUROTRAC ISS Part 2, pp. 66-74, 1993, unpublished.

Wagner, S. in Greenhouse Gases, Isotopes and Trace Elements in Glaciers as Climatic Evidence of the Holocene, W. Haeberli and B. Stauffer (eds.) pp. 33-39, Report of the ESF/EPC Workshop, Zurich, 27-28 October 1992, 1994, unpublished.

Whitlow, S., P. Mayewski, J. Dibb, G. Holdsworth and M. Twickler, An ice-core-based record of biomass burning in the Arctic and Subarctic, 1750-1980. Tellus, 46B, 234-242, 1994.

(Received: June 4, 1996; revised: July 25, 1996; accepted: August 13; 1996.) 